\title{
Transitional borders and intermedial spectacle: Kiarostami and opera, between France and Iran
}

Article

Accepted Version

Chamarette, J. ORCID: https://orcid.org/0000-0003-0701-1514 (2013) Transitional borders and intermedial spectacle:

Kiarostami and opera, between France and Iran. Studies in French Cinema, 13 (3). pp. 257-271. ISSN 1471-5880 doi: https://doi.org/10.1386/sfc.13.3.257_1 Available at https://centaur.reading.ac.uk/92947/

It is advisable to refer to the publisher's version if you intend to cite from the work. See Guidance on citing.

To link to this article DOI: http://dx.doi.org/10.1386/sfc.13.3.257_1

Publisher: Intellect

All outputs in CentAUR are protected by Intellectual Property Rights law, including copyright law. Copyright and IPR is retained by the creators or other copyright holders. Terms and conditions for use of this material are defined in the End User Agreement.

www.reading.ac.uk/centaur 
Central Archive at the University of Reading

Reading's research outputs online 
Author's Original Manuscript: this article was published in Studies in French Cinema 13:3, 257-271 (November 2013)

Transitional borders and intermedial spectacle: Kiarostami and opera, between France and Iran

Jenny Chamarette, Queen Mary, University of London

\begin{abstract}
This article discusses the complex cultural and theoretical relationships between France and Iran, Europe and the Middle East in recent intermedial work by the film-maker Abbas Kiarostami. Through the installation Looking At Tazieh (2004), the film Shirin (2008) and the staging and direction of the opera Cosi fan tutte, the article explores the philosophical and contextual implications of spectacle within these trans-cultural productions. In particular, it discusses how French cultural interventions into Kiarostami's recent intermedial work can be rethought productively outside the remit of francophone or transnational cinemas, instead refocusing on the intermediality of spectacle and modes of enculturated looking in these three recent productions.

\section{Keywords}

Intermediality; spectacle; opera; installation; spectatorship; Kiarostami
\end{abstract}


As older paradigms of national cinema have been replaced gradually by new paradigms beyond national, linguistic, socio-cultural and political boundaries, Studies in French Cinema has played a key role in identifying key debates in transnational, Maghrebi and francophone Cinemas (see Higbee 2007; Tarr 2011). As Susan Hayward's critical engagements with national cinemas have shown, the question of the national is always implicitly concerned with the mutable and permeable borders between cinematic modes of production in overlapping cultural, social and geographical spheres (2005). In turn, modes of cultural production within and outside France have an on-going relationship to the complex entities, which loosely and often contradictorily constitute French Cinema.

This article is concerned predominantly with spectacle, and in particular, with modes of spectacle that shift dramatically across the borders of geography, art forms and visual cultures. This concern with spectacle, its intermediality and indeed its indeterminacy, forms a key part of my argument surrounding the continuing difficulties of generic, linguistic and geographical categorization, which in turn challenge some of the concepts of French and francophone cinema that are currently in circulation in French Studies. By including opera within this formation, I am making reference to a specific, multimodal art form, which is also more locally specific to certain 200-300-year-old artmaking practices, situated predominantly within Europe.

In my discussion of opera as spectacle, I attend to interrelationships in the multimodal work of Abbas Kiarostami between European conventions of spectacle, and those of Iran. I outline the transitional and intermedial position of Iranian spectacle and European opera with relation to the filmic practices of Kiarostami, and by doing so, expose my own temerity in drawing upon a dramatically different art form to that of 
cinema, from a significantly different cultural perspective to that of France. Nonetheless, this potentially profane alignment of film and opera is not unprecedented in anglophone or French-speaking philosophies and theories of visual culture. The film philosopher Stanley Cavell has explored the tentative relationships between ontologies of opera and film, suggesting the following: 'I have in the past couple of years been experimenting with the idea that what happened to opera as an institution is that it transformed itself into film, that film is, or was, our opera' (1994: 136). Here Cavell does not simply refer to the emotional dynamics of opera, which gained a new form in the emotional forces of classical Hollywood genre film-making; he also refers to a relational connection between opera and cinema, in terms of the spectacle of woman, and the inarticulacy, or inarticulability of her voice.

The elements of spectacle, which are both intermedial and transitional, both gendered and affectively dynamic, both culturally encoded and culturally fluid, are articulated in this article, around three very different works by Kiarostami: installation, film and opera. The three parts of this article: installation - Looking at Tazieh (2004), film - Shirin (Kiarostami, 2008), and opera - Cosi fan tutte (2008/2009), speak to the transitional borders and the intermediality of spectacle found in the works' relationships between France and Iran, between Europe and the Middle East. Furthermore, these transitional and intermedial modes of spectacle evince a new exploration of cinematic practices that are closely allied to a French context, and which nonetheless depart from national or postcolonial theoretical frameworks pertaining to French cinema, or indeed francophone cinema. Perhaps they also engage critically with the limitations of thinking 
'transnationally' about cinematic practices where what is a stake is less to do with nationhood, than enculturated modes of looking.

The structures, forms and distribution networks of Kiarostami's films and moving image works map a complex set of correspondences between France and Iran, and between European and Middle Eastern cultural performances and film techniques. Looking at Tazieh, Kiarostami's moving image installation from 2004 is one example of this, but other fruitful encounters might be found in his recent films, Shirin and Copie conforme (2010), and Kiarostami's direction and staging of Mozart's opera Cosi fan tutte, in a collaboration between the English National Opera and the Festival d'Arts Lyrique in Aix-en-Provence in 2008 and 2009.

Kiarostami's films have been elevated to the discourse of contemporary French philosophy, receiving close attention from philosophers and theorists in France such as Jean-Luc Nancy, Marie-José Mondzain, and Jean-Louis Commolli; and prominently from Laura Mulvey and Hamid Naficy in an anglophone context (see Naficy 2001; Nancy and Kiarostami 2001; Mulvey 2005; Mondzain 2007; Commolli 2012). His films have received their broadest reception within French film distribution networks, in particular via the French and European film festivals circuit, the juries on many of which Kiarostami has sat, including at Cannes in 1993, 2002 and 2005. French television and film production companies have been instrumental to the funding of his films (MK2 and Canal+ particularly), and his on-going creative relationship with the French actress, Juliette Binoche, has cemented a continued investment in and negotiation with the cultural structures of France in the dissemination of his work. 
By the same token, Kiarostami's films have been denied a license in Iran for over fifteen years, although in the past year this situation has slowly begun to change, including a screening of Shirin in Tehran in January 2012 (Anon. 2012). Herein lies part of the conundrum of the complex cultural claims laid to his work: Kiarostami has always described himself as an Iranian film-maker, and refuses to identify as European or 'transnational', and certainly not as francophone. He continues to live in Iran, though both of his most recent films - Copie conforme and Like Someone In Love (Kiarostami, 2012) - have been shot outside Iran, in Italy and Japan, respectively. And yet much scholarship on Kiarostami, in France and elsewhere, has tended towards an interpretation that implicitly or explicitly classifies him as a European auteur. Alberto Elena points out this stumbling block in the appropriation of Kiarostami to a western cultural heritage, explaining that:

The long-standing and widespread overuse of Western references when analysing Kiarostami's films (Rossellini, De Sica, Olmi, Bresson, Godard, Murnau, Tati and even Eastern maestros such as Ray and Kurosawa, already victims of a similar exercise) has for a long time obscured the deep-rooted Persian influence on his films. (2005: 186)

In a kind of reverse-orientalism, Kiarostami is often constructed within the canon of European auteurist film-makers, revealing the tacitly Eurocentric conventions of auteurist discourses as much as the viewing practices of scholar-critics. As the New York 
film critic Godfrey Cheshire has pointed out with relation to Copie conforme (revealing his own occidental values as he does so):

For Iran's most celebrated director $[\ldots]$ a brand name in Western art houses since the 1990s, maintaining an identification with Iran is evidently not as much of a concern anymore; as an auteur, he now belongs to the world [...] Certified Copy looks not only like a European art film but also like a specific subgenre of that form that was proudly exported, especially by France and Italy, from the fifties through the seventies. (2012)

However, it is not the case that all critics have unfairly appropriated Kiarostami into a European canon. Kiarostami's most recent work appears equally to court this appearance of Europeanness, in particular of a so-called 'French' subgenre. Even prior to these productions, connections to European thought and visual culture in his works are not entirely unsubstantiated. Critics such as Cheshire and Sylvie Rollet have engaged with the Iranian-ness of Kiarostami's cinema, exploring the films' relationships to forms of Persian art and poetry that privilege repetition, ornamentation, and the elision of the past, present and future on one plane (Rollet 1997). Both Elena and Mulvey point to these repetitions and ellipses as an evocation of principles of uncertainty: in this light, it is perhaps unsurprising that the allied implications of reflexivity, uncertainty and repetition in Kiarostami's work would also find a welcome audience with contemporary French philosophers of ethics and aesthetics such as Nancy and Mondzain (Elena 2005: 188-89; Mulvey 2005). The affinities between discontinuity and repetition in Kiarostami's 
cinema, and in European postmodern thought, create productive connections between the two. Nonetheless, it is, all the same, important not to claim postmodernity for Kiarostami's films, nor to discuss Iranian-ness and European postmodernity interchangeably. As Mulvey has eloquently argued, the popularity of Kiarostami's cinema in Europe and beyond should not be considered solely as a culturally imperialist appropriation of Kiarostami as an auteur, but rather an invitation simultaneously to interrogate the politics of representation and 'a politics of cultural specificity at a time of increasingly encroaching cultural homogenization' (Mulvey 2002: 261). In order to explore this interface between Eurocentric postmodernity and Iranian cultural specificity, I will first turn to Mondzain's response to Kiarostami's installation, Looking At Tazieh, and its implications for reflecting upon intermedial spectacle, and transitional modes of looking.

\section{Installation: Looking at Tazieh (2004)}

In 2004, the Kunstfestival des Arts Bruxelles welcomed a series of screenings of Abbas Kiarostami's installation, Looking at Tazieh. The 77-minute moving image installation treated as its subject the public performance of the Ta'zieh, a traditional Persian Shi'ite passion play. The $\mathrm{Ta}$ 'zieh itself is one of the only permitted forms of public spectacle and ritual performance cultures of Shi'a Islam, and forms part of a complex set of mourning rituals that take place during the first month of the Muslim lunar calendar, Muharram. The ritual commemorates, through its performance and in the emotional responses of its audiences, the power struggles for leadership of Islam, after the death of the prophet Muhammad in AD632, who left behind him no male heir. These bloody struggles for 
leadership reached their apex, and the moment from which the narrative of the performance unfolds, in the martyrdom of Hussein, the grandson of Muhammad, who died in battle on the plain of Karbala (in modern day Iraq) at the hands of an opposing army (which would eventually lead to the dynastic rule of Sunni Islam). The moment of Hussein's death is also effectively the moment of the emergence of Shi'a Islam. As Rebecca Ansary Pettys describes it, the death of Hussein not only sets the scene for martyrdom; it also constitutes a 'divisive rift within Islam', and consequently, 'the Shi'yah mourning ritual commemorates the birth of the Shi'yah sect' (1981: 344). This too is closely linked to a commemoration of the birth of Persia as a dynasty and nation distinct from Arab rule. By consequence, ritual play, religion and nationhood are closely intertwined in the performance of the Ta'zieh (Ansary Pettys 1981).

My brief account here is, inevitably, an oversimplification of a complex set of relationships between performance, ritual, religion, geo-politics and national identity. However, I am not aiming to describe the fullness of the complexity of the $\mathrm{Ta}$ 'zieh performance, not least because of the strict limitations to the conditions of viewing that Kiarostami's installation Looking at Tazieh afforded. However, examining the spectacle of Looking at Tazieh not only elucidates this inevitable process of contextual oversimplification, but also highlights both the complex underpinnings of cultural performance, and the limitations of such contexts when brought to bear in the case of the installed moving image.

In Looking at Tazieh, Kiarostami's installation piece, the drama and affective power of the spectacle and performance of the Ta'zieh unfolded via three devices: two of projection and one of transmission. The events that unfolded were arranged across two 
large black and white screens, and one small colour television screen, featuring centrally in the installation. The tiny central television screen displayed a documentary of the Ta'zieh play. Via two large screen projections to the left and right of this tiny screen, the bodily responses of the Ta'zieh's audiences were presented, segregated by gender on the left-hand (female) and right-hand (male) screens, respectively. This segregation of gender between two screens, physically separated by a recording of the spectacle itself, imitated the gender segregation considered the norm in any performance of the Ta'zieh.

Consequently, both the focus of the on-screen audience's attention (the performance of the Ta'zieh) and the recording of the on-screen audience's physical and emotional participation within that spectacle, were opened out and presented across one horizontal plane, in three different screening positions, and coded by gender. Rather than mirroring one another, the spaces of performance and the spaces of response were flattened, and prised open, to create a third location of viewing: that of the observers within the installation space. Speaking of her own responses to Looking at Tazieh, in 2004, the philosopher and scholar Mondzain wrote the following:

What place should I make in my memory as well as in my present life for a drama inscribed in a culture that is entirely alien to me, and which is furthermore presented in a language that I do not know? [...] The answer lies not in the word Tazieh but in the expression Looking at [...] This is not solely concerned with what it is that separates the Iranian people and that also reunites them across history; it is also concerned with what it is that separates us from this world. What is suddenly made to emerge from out of 
the blue is an entirely unlikely, perhaps impossible proximity. To participate in a spectacle is always to share in a proximity which sets about proving that act of sharing (2007: 19, my translation).

Mondzain's response emphasizes the incomprehensibility, and perhaps the incommensurability, of European modes of looking on the one hand, and Iranian modes of looking on the other. When placed before the spectacle of an Iranian passion play, what possible understanding, she asks, can a European spectator have, unaware of the cultural signification of the Tazieh, not situated within this vast public spectacle that forms such a crucial part of Persian heritage, nor within the formal gender segregation of Iranian cultural life? The answer, Mondzain claims, is in the presence of spectacle itself. Public spectacle, and participation within the field of public spectacle, draws attention to ways of looking, to the emotional responsiveness of audiences as they look, and to their affective participation within that public field. Kiarostami's installation, in the eyes of Mondzain, produces just such an effect. At the end of her piece, she argues:

Culture appears here as that which, in its respect for difference, produces a relationship of universal recognition between subjects. Emotion is not an originary or natural grounds which would merge those subjects separated by everything; it is on the contrary the intimate figure of that which plays at the heart of the gestures of art: the universality of a shared condition in the community created by the spectacle. (Mondzain 2007: 19, my translation) 
Mondzain emphasizes affect, not quite as a universally shared quality, but rather as caught up in an intimate set of gestures of artistic expression. If there is a form of universality - an emotional connection of sorts - which has been noted by critics in their descriptions of Looking At Tazieh, then this universality is only apparent as a condition of spectacle itself. The production and mediation of spectacle, from performance to installation, forges an uncomfortable relationship between contextual ignorance and a transmitted, possibly shared sentiment. The European observers at Brussels in 2004, and at the Edinburgh Festival in 2008 where it was later screened, would and could know very little about the rich cultural history of the Tazieh, and yet, still they responded emotionally to the emotional responses of the on-screen spectators (McMillan 2008). While Mondzain's position emphasizes universality as a shared condition, which emerges from the communities of spectacle, one might equally underscore the limitations of these processes of community production. As Frédéric Sabouraud underlines in his recent monograph, the encounter with the installation is one of partiality. In moving from one screen to another, there are always parts in between that are missed (Sabouraud 2010: 244). The irony of this statement of course, and one which may indeed account for a crucial function of Looking At Tazieh, is that by reducing the performance of the Tazieh to an installed set of screens - either to a quasi-ethnographic colour television documentary of one single performed instance, or to the enlarged, black and white faces of those individuals present and emotionally committed to that performance - the blackened spaces between these images open up, and make embarrassingly apparent, a lacuna in the knowledge or understanding of European audiences vis-à-vis the 
significance of the Tazieh to Iran, to Persianness, and to Shi'a Islam. Simply put:

European audiences cannot possibly participate knowingly in the affective and cultural logic of the performance. Instead, partiality and non-knowledge form crucial elements within the functioning of the installation, and are for European audiences elements as fundamental to it as a shared spectacular community, or a background understanding of the Tazieh rituals (oversimplified and insufficient as this understanding inevitably will be).

I want to take forward the ways in which Mondzain's and Sabouraud's responses highlight the paradoxical incommensurabilities between France and Iran, between medial art forms such as performance, installation, film and opera, and between knowledge and affect, that are exposed by Kiarostami's recent projects in opera, installation and film. The indeterminate limits of cultural and affective knowledge within these modes of spectacle also invoke questions of cultural and epistemological borders, and what occurs when those borders are displaced or rendered transitional. These intermedial modes of spectacle also invoke the limitations of shared affect, which resonate with the work of thinkers such as Mondzain and Nancy. Such modes raise the issue of the phenomenological indeterminacy of visual spectacle. In turn, this phenomenological indeterminacy opens up a 'productive betweenness' of thought, which reflects upon the interstitial position of Kiarostami's works along geographical and political borders, as well as experiential and philosophical ones. 


\section{Film: Shirin (2008)}

Looking at Tazieh was simultaneously an installation of a performance elsewhere, and a performance of audiences in front of other audiences. In its conceptual relations to spectacle and looking, it foregrounds key principles which also operate in Kiarostami's film of 2008, Shirin. In Shirin, however, the space of the recorded performance - the third screen in Looking at Tazieh - is totally elided in favour of a single plane of viewing. What we see, in Shirin, is the audience of the spectacle, rather than the spectacle itself. In effect, Shirin magnifies and intensifies the plane of viewing, and of looking, and in doing so, shifts the borders of 'film' into the intermedial spaces of spectacle.

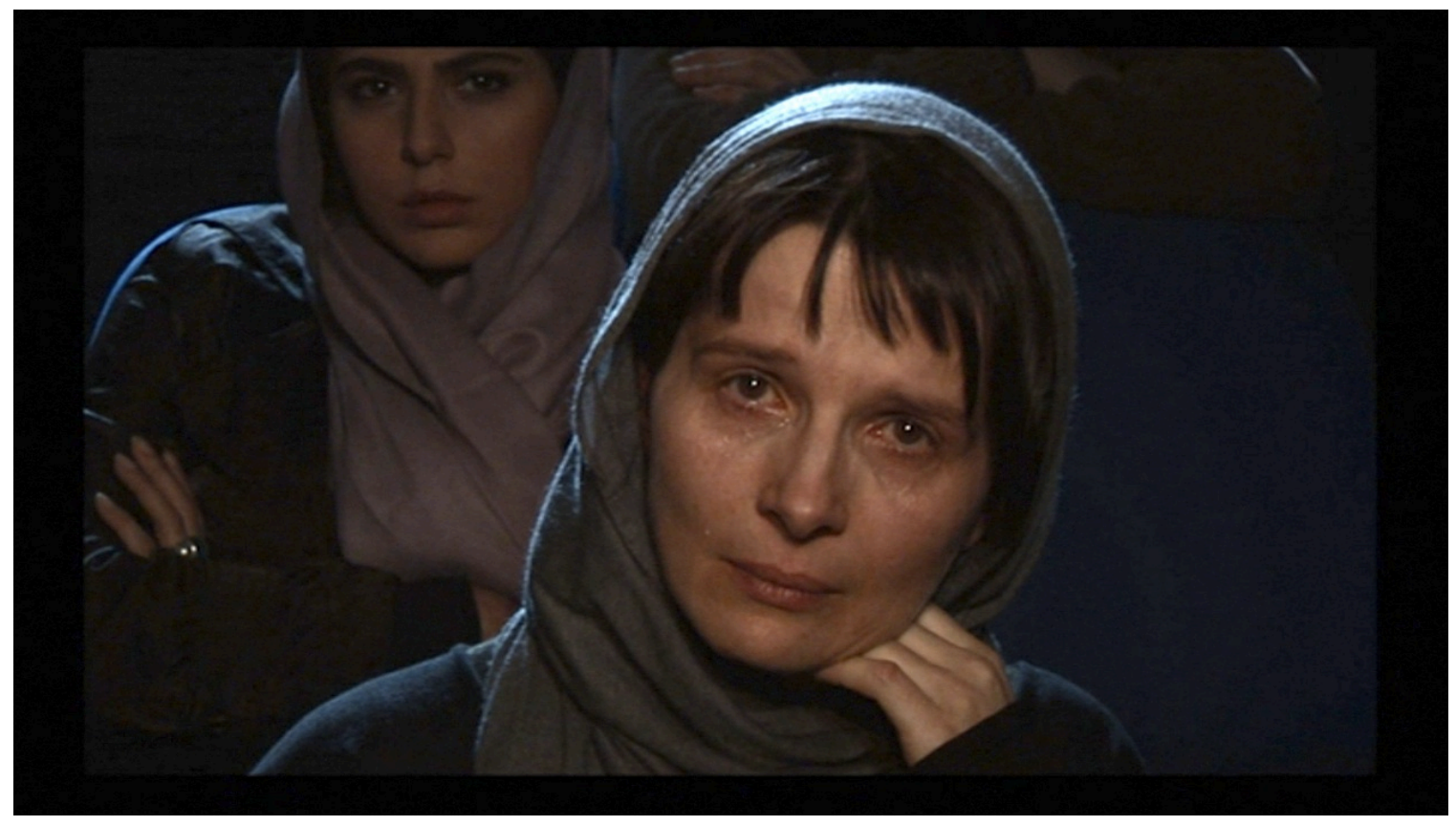



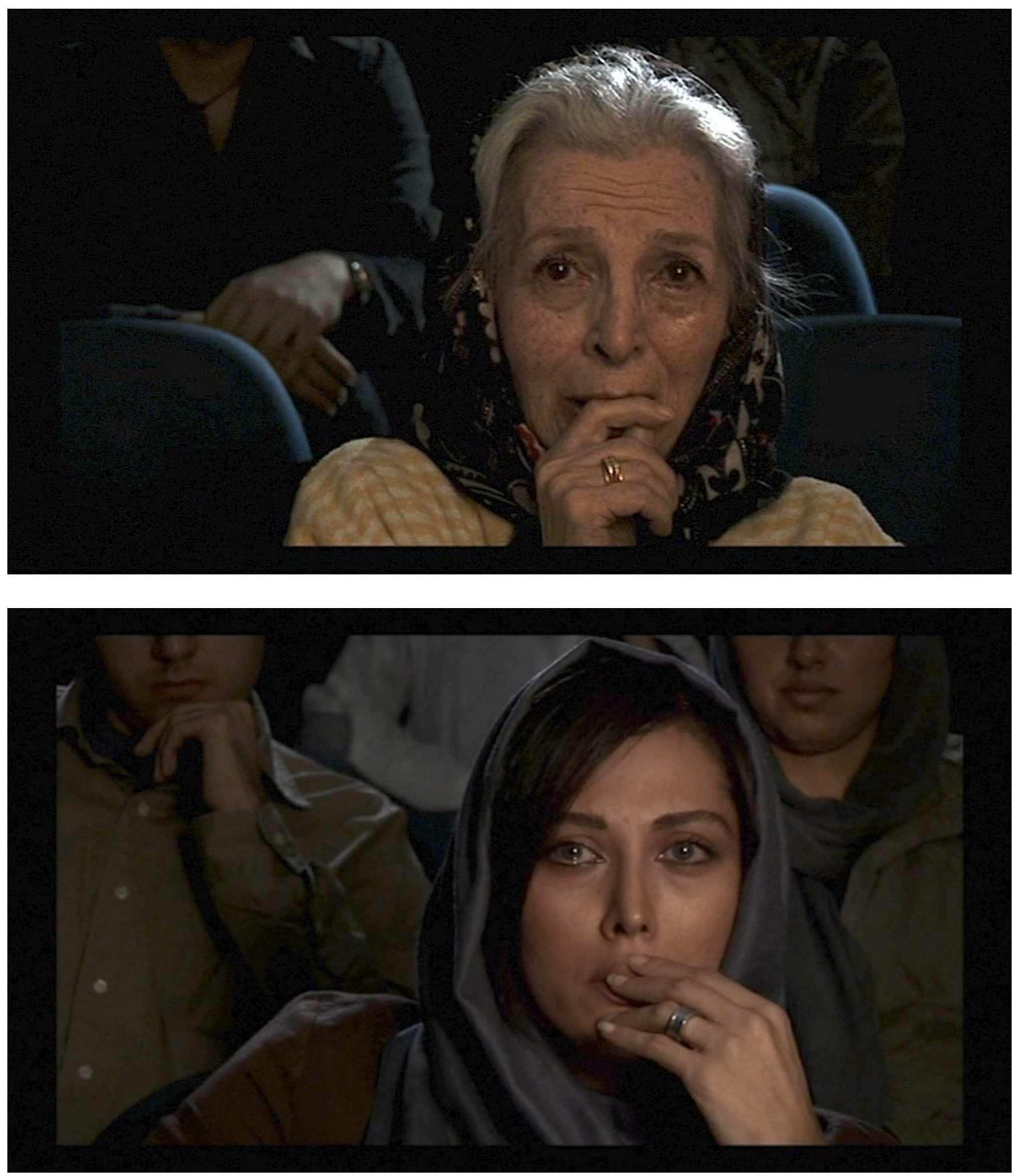

- 14 - 


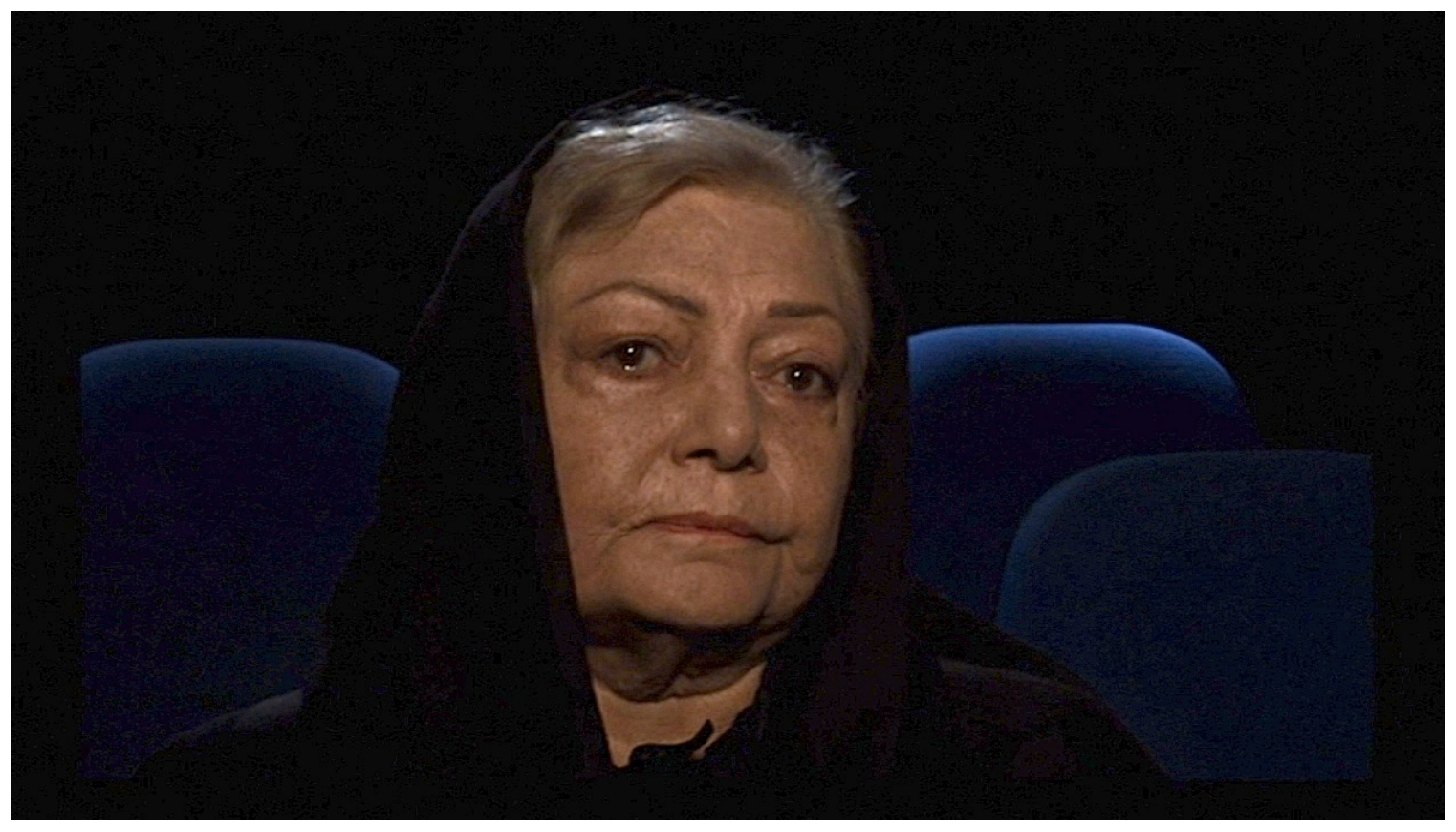

Figures1-4: Images from the closing minutes of Shirin (courtesy of Cinema Guild).

Critics such as Rollet, Elena and S. Saljoughi suggest that Kiarostami’s work has its closest affinities with poetry, both medieval Islamic and contemporary modernist (Saljoughi 2012). Elena, in particular, argues that Kiarostami’s films encourage reflection upon the affinities of poetic expression (Elena 2005: 189-95). Shirin is perhaps the most concrete example of this intermedial proximity between poetry and cinema. The diegesis takes place entirely within a cinema auditorium, and the film itself has been described as 'a film within a film', whose screen and visual action we never see. Only the faces of over 100 famous Iranian actresses (and the French actress Juliette Binoche), heads wreathed in a veil, are exposed over 90 minutes of screen time, each responding with microexpressions of joy, boredom, satisfaction, sensuality and grief (see Figures 1-4). The soundtrack is exclusively that of the film we never see: an enactment of the medieval Islamic epic poem, 'Khosrow u Shirin', whose ill-fated heroine, Shirin, is tormented by a 
love that is never sated. She is one of a pair of star-crossed lovers, and she tells her retrospective narrative from the deathbed of her slain husband, Khosrow, former King of Iran. Shirin's strength, beauty and sensuality are emphasized in Nizami of Ganjeh's twelfth-century poem, as well as in the audio screenplay of the film, written by Mohammad Rahmanian. The 'imaginary' screen, whose only visual traces lie in the undulations of light across the background of the auditorium, behind the face of each actress, emphasizes in its soundtrack breath, water, the sounds of wind, the rustle of cloth, and the rich, sensuous timbre of Shirin's voice. The film also emphasizes musical interludes, which, in the absence of diegetic visual clues to the on-screen 'imaginary film', seem to foreground heightened moments of attention whereby the diegesis of the film-within-the-film falls away, leaving behind the faces of the female spectators, upon which the audience beyond the screen can dwell. During these musical sequences, it seems too that the most emotionally touching expressions cross the faces of the actressspectators: tears, rapt attention and deep sadness.

Shirin is also entirely a film of artifice: it was created when Kiarostami asked each actress to imagine her own internal film about love, and to perform in front of the camera for six minutes each (Jaggi 2009). The invisible 'sound film', which we never encounter fully visually, but can only hear and see through the act of others seeing, was added once filming was complete. And yet, sound editing and matching visual cuts resonate with the bodily movements of the actresses, who appear to recoil before acts of violence, and avert their eyes in moments of great sadness. As spectators of spectators, we see the film through their eyes: it is only through their responses, and our ability to listen, that we can evoke sense, and affect, from the film's narrative. 
The relationship between performance and indeterminate, intermedial spectacle seems irrevocably linked in Shirin. The film Shirin naturally refers to this great epic poem of lament, but it also enacts the poem by calling its doubled audiences towards it. The closing lines of the film's subtitles state, in Shirin's voice: 'And here we are, Khosrow and I, and you, my grieving sisters. You look at his dead body, and you cry. You listen to my story, and you cry. Through these tears, I see your eyes. Are you shedding these tears for me, Shirin? Or for the Shirin that hides in each one of you?' This reflexive gesture interpellates both the seated, represented, female spectators, and the spectators of those spectators - the film's audience. We are not interpellated into the film's diegesis however (the actresses are after all, not looking at the spectators beyond the screen, but diegetically towards a screen that we are not party to), but back to what it is that allows, and disallows, the sharing of affect. In other words, this self-reflexive call to audiences combines both an intimation of what it is that allows us to participate in spectacle, and even to feel moved by it, and a reminder that claiming to understand, to know, and to share affect would also implicate an elision of crucial cultural differences. Nonetheless, in its reflexive claims to the universality of feminine experience, this gesture also catches audiences up short. For what have we actually seen, except for the ways that others look at a film that we cannot see ourselves? Saljoughi argues that the inclusion of 113 Iranian actresses 'pays homage to the history of Iranian cinema and television' and Juliette Binoche 'serves as an index for European cinema in the same way that the Iranian actresses' faces point to the work of Kiarostami's colleagues at home' (Saljoughi 2012: 526). However, even this contextualized experience of spectatorship onscreen highlights the affective disjunctures between contextual knowledge and emotional 
response on the part of audiences. It would seem that the limitations of knowledge, knowledge of European and Iranian Cinema, and of cultural borders, also operate as limitations upon affective relations to the screen, alternately directing and misdirecting the possibility of intercultural affect.

Spectatorship in Shirin is partially closed off to the cultural constructs from which a work emerges: in the midst of viewing, spectators both see and cannot see. Shirin's predominant exhibition in Western Europe doubly circumvents the possibility of seeing from a Persian cultural perspective, invoked visually and intertextually via the film's content. This cultural indeterminacy of spectacle, then, emerges both in Looking at Tazieh, a moving image installation involving flesh and blood spectators in the midst of its screening spaces, and in Shirin, a film whose format permits spectatorship from a distance, on DVD format, but where both limit the very possibility of 'seeing' as 'knowing', or even as 'sharing affect'.

Nancy's essay on Kiarostami, 'The Evidence of Film', brings pertinent insights to bear on indeterminate spectacle and the borders between knowing and seeing, between the worlds of the visible, and the world beyond the visible. When Nancy describes film as an 'opening on to the world', it is strictly not in the sense of film's representational capacity, but rather a means by which the world comes to the image through the acts of the camera (Nancy and Kiarostami 2001: 17). Nancy describes not a representational world, but rather one that is somehow always beyond the grasp of representation: the world, which we, paradoxically and uneasily, inhabit (cf. James 2007: 68). Nonetheless, it would be too easy to draw a parallel between the 'invisible world' beyond the screen towards which Shirin is constantly pointing, and the inhabited world beyond 
representation that is ours. In the first instance, this would do a grave injustice to the content of that world beyond the screen: Shirin u Khosrow is not an epic poem embedded within the cultural logic of European spectators. It is not 'our' world, and in fact, it raises difficult philosophical and phenomenological questions about the nature of that scholarly 'us' from which we might be authorized to position ourselves. While its narrative superstructures may resonate with Dido and Aeneas, or Romeo and Juliet, Shirin resolutely retains its sense of its Persianness. And yet, the acknowledgement of unknowability is foregrounded in its narratives, its sounds, and its striking visual form, facing away from the imagined image, rather than oriented towards a represented image.

If unknowability and indeterminacy are fundamental structuring devices, both for Looking At Tazieh and for Shirin, then this begs the question as to why a discussion of Kiarostami's work should necessitate reflection within a French context at all. Why should this installation and film pose a challenge to notions of postcolonial francophone or transnational cinema, when it would be easier to consider his work to date as residing firmly outside the borders of France, and instead to orient the installation and film towards a phenomenologically inflected, albeit predominantly French-speaking philosophical methodology? The responses to these questions lie in both the theoretical and industrial contexts to Kiarostami's films, installations, exhibitions and spectacles (and opera).

First, it would be disingenuous to suggest that France, French spectatorship, scholarship, distribution, festivals and cultural esteem have not played a major role in the formation and visibility of Kiarostami's work to date. Both the theoretical affinities with French thinkers of the visual, such as Mondzain and Nancy, and the complex industrial 
contexts that make Kiarostami's work visible, and which would not otherwise allow him to continue to make work, emphasize the on-going importance of Kiarostami's role within France. To imagine that the writings of Mondzain or Nancy fully transcend the European and French cultural and philosophical traditions from which they emerge would be deceptive, and yet the intertwining of Nancy's thought and Kiarostami's filmmaking suggests a complex relationship between western and middle-eastern cultural activity. There should be a way of recognizing the intermedial interchange in play, both in the substance of Kiarostami's work, and in the mode of its transmission, in France, Europe and beyond. W. Higbee and S. Hwee-Lim's model of 'critical transnationalism' are a productive means of discussing this theoretical and conceptual hybridity, though the task of outlining a working model of this kind exceeds the remit of this article (2010).

Kiarostami's films and installations are seldom viewed, and often prohibited in Iran, but Kiarostami is not an exiled figure; he returns to Iran and continues to reside there. His works become visible predominantly through the mechanisms of French and European cultural production, but they equally resist easy absorption into discourses and visual modes that are culturally French. However, this resistance to cultural absorption should be noted both in accounts of industrial context, and in the means by which a fruitful theoretical or philosophical engagement with Kiarostami's works can be established. My argument has, so far, shifted between these poles in order to acknowledge, but not to overplay, the significance of France in Kiarostami's dialogues between European and Iranian spectacle. In my final section, dialogues between these two enculturated modes of spectacle are further complicated through an interrogation of operatic performance and staging. 


\section{Opera: Così fan tutte}

Over the 2008-2009 season, Kiarostami was commissioned to direct an operatic production of Cosi fan tutte, Mozart's opera, co-funded and co-produced between the English National Opera and the Festival d'Arts Lyrique in Aix-en-Provence. One of the events overshadowing the opening of the ENO's London co-production in 2009 was the British Embassy in Tehran's requirement that Kiarostami provide a deposit, to guarantee that he would not flee Iran and seek permanent residence in the United Kingdom. As the press recorded, Kiarostami grew so weary of the bureaucracy surrounding his visa application that he did not attend any of the performances in the United Kingdom and instead left the day-to-day direction in the hands of his assistant, Elaine Tyler-Hall (Higgins 2009). And yet, in the opera's first incarnation in Aix-en-Provence in 2008, Kiarostami had no such trouble. One can only speculate as to the reasons for this, but one might imagine that the cultural capital Kiarostami holds in France far exceeds his influence in the United Kingdom, and that this might also speak volumes to the respective esteem of international cultural capital in the United Kingdom and in France. The Aix cast of Cosi also included the British operatic baritone William Shimell, who stars alongside Juliette Binoche in Kiarostami’s first film located in Europe, Copie conforme, in 2010.

In both performances in Aix-en-Provence and in London, the set design of the stage was constructed around a large screen, onto which slow-moving images were projected. These film-tableaux served as a cinematic backdrop to the operatic performance, providing a constant among the many scene changes, which were 
choreographed onstage with manipulable props (Libiot 2008). Filmed backdrops for Cosi fan tutte may have varied slightly between the two main seasons in Aix and London: in Aix, lengthy projections of the Calanques peninsular formations off the coast of Marseille took up most of the rear projection, whereas press reception in London (perhaps erroneously) describes projections of the bay of Naples, contemporary café sequences, and a projection of the orchestra as backdrop in the final scenes of the two act performance (Church 2009; Fairman 2009). Responding to criticism that these lengthy filmed takes were distractions to audiences engrossed in the action of the performance, Kiarostami responded in an interview in the Financial Times that

the screened backdrops $[\ldots]$ act as a reminder to the audience that it is present. 'You don't have to forget about yourself to get involved in the story [... the opera] is a matter of portraying emotions. And how can we relate to those emotions if we forget about ourselves? How can we even pretend that we can ever forget about ourselves?'(Aspden 2009)

In the midst of a renowned, canonical, European opera, it would seem that Kiarostami sought to defamiliarize audiences with their cathartic expectations of the performance of operatic spectacle, via an unobtrusive, unyielding moving image as background to the action. As critics noted, the moving images of Kiarostami's set induced a split between the fantastical, suspended realm of operatic spectacle, and a relation to more everyday circumstances of human experience. The use of the moving image within operatic set design is not unique: in the 2008-2009 season at the Opéra 
National de Paris, Richard Wagner's Tristan und Isolde included moving image set design by the video installation artist Bill Viola. Viola's ghostly images of bodies in water draw clearly upon an aesthetic of corporeal transcendence typical to Viola's work, as he describes in the catalogue: 'The images are intended to function as symbolic, inner representations that become, $[\ldots]$ "reflections of the spiritual world in the mirror of the material and the temporal"' (Viola 2008: 34). Kiarostami's sets, however, appealed to the prolonged everyday, rather than the symbolic realm.

Cavell's comments on film and opera noted early in this article bear resonances with Viola and Kiarostami here. The nature of affective spectacle carries over between opera and film, evocative of the division of the world between the fantastical and the real. In Cavell's essay, 'Opera and the lease of voice', he describes the philosophical relation in opera between the 'sensuous and the super-sensuous' - a leap between two worlds:

we may leap, as it were, from a judgment of the world as unreal, or alien, to an encompassing sense of another realm flush with this one, into which there is no good reason we do not or cannot step, unless opera works out the reasons. [...] This expression of the inexpressible (for there is no standing language of that other world; it requires understanding without meaning) I described as a mad state, as if opera is naturally pitched at this brink. (Cavell 1994: 144)

Though almost the entirety of Cavell's essay is devoted to singing and the problem of 'speaking' or issuing voice in the world, particularly the problem, or even the impossibility, of woman's 'speech' in the world, the relation between two worlds in 
opera seems to be one divided by vision and spectacle on the one hand, and singing, breath and hearing on the other. The visual and the audible, within opera, become elements that both transcend and mediate the possibility of being at once within the world of everyday experience, and transported to another place of experience. In effect, the moment I believe Cavell to be describing is the moment of affective intensity, of being moved by the performance and spectacle of opera, and of singing in particular. And yet singing here, for Cavell, seems to at once collapse the singer, the spectacle and the audience. This kind of transcendent moment, where worlds meet, is precisely the kind of epiphanic moment that Richard Rushton used to describe, using Heideggerian phenomenology, the affective, rather than interpellatory, power of Shirin at a conference on Film-Phenomenology at Queen Mary, University of London, organized by Lucy Bolton in 2010. The intermedial spectacle of moving image and opera suggest the possibility for culturally specific affective intensity, despite the opposed worlds that they open up alongside one another.

In spite of the dramatically different traditions of spectacle, there is a notion of transitional, affective intermediality that makes a shift from the Iranian heritage of epic poetry and religious performance in Shirin and Looking at Tazieh, respectively, to a European heritage of music and operatic performance in the direction and set design of Cosi fan tutte, itself of course an eighteenth-century historical mix of European genres, languages and musical and visual composition. This transition of the spectacle from cinema to opera is perhaps not so incongruous given the constantly shifting grounds of spectatorship, distance and proximity in the films and installations discussed this far. Indeed, the relation between worlds - the worlds of existence, and the world 'beyond a 
concept' of Cavell, or the 'opening onto the world' of Nancy - suggest that, while there is an uncloseable gap between cultural forms of looking in all three works, an engagement with the intermediality, and the indeterminacy, of spectacle might recognize ways in which that uncloseable gap can be articulated and acknowledged. Such an articulation can review questions of the 'French', the 'francophone' and the transnational in debates around new cinematic forms, in favour of an engagement with enculturated, mediated modes of looking at spectacle.

In conclusion, Kiarostami's recent work in installations (Looking at Tazieh), film (Shirin, Copie conforme), opera (Cosi fan tutte), engage with processes of looking and attending that are situated, enculturated, affective and contextual. These works appear to recognize the incommensurable gap between looking as an Iranian and looking from the perspective of the European, high-brow cultural environments in which Kiarostami's work circulates. Yet in these works, multiple modes of looking abut one another: in Shirin as in Looking at Tazieh, we are looking at looking, spectacularizing the spectacle in a manner that acknowledges this incommensurability, but attempts to bring the two cultural spaces of looking together nonetheless. From Iran, to France, Belgium to Scotland, Persia to Europe, the shifting cultural, industrial and theoretical grounds of Kiarostami's work challenge the conceptual and affective bases from which we begin to make claims about cultural activity. The critical concepts of 'francophone cinema' and 'critical transnationalism' are precisely those notions that are challenged by Kiarostami's on-going cultural interventions with the moving image. Shifting the transitional and intermedial borders between France and Iran, the installation, films and opera all circulate within an indeterminacy of spectacle. This indeterminacy may also indicate the ways in 
which we are always both looking at and not fully knowing, participating in, but not sharing, our audio-visually mediated, affectively complex experiences of the world.

\section{References}

Anon. (2012), 'Kiarostami to return with "Shirin” charity screenings', Tehran Times, 8 January, http://www.tehrantimes.com/component/content/article/94299. Accessed 30 November 2012.

Ansary Pettys, R. (1981), 'The Ta'zieh: Ritual enactment of Persian renewal', Theatre Journal, 33:3, pp. 341-54.

Aspden, P. (2009), ‘An Iranian director talks about censorship', Financial Times, 30 May, http://www.ft.com/cms/s/0/95ecdfa2-4be8-11de-b82700144feabdc0.html\#axzz2DuZ6XQZH. Accessed 10 April 2012.

Cavell, S. (1994), A Pitch of Philosophy: Autobiographical Exercises, Cambridge, MA: Harvard University Press.

Cheshire, G. (2012), 'Certified Copy: At home and abroad', Current, http://www.criterion.com/current/posts/2303-certified-copy-at-home-and-abroad. Accessed 16 June 2012. 
Church, M. (2009), 'Kiarostami and Minghella: ENO film directors', The Independent, 23 June, http://blogs.independent.co.uk/2009/06/23/kiarostami-and-minghella-enofilm-directors/. Accessed 2 November 2012.

Commolli, J.-L. (2012), Corps et cadre: cinéma, éthique, politique, Paris: Verdier.

Elena, A. (2005), The Cinema of Abbas Kiarostami (trans. B. Coombes), London: Saqi in association with Iran Heritage Foundation.

Fairman, R. (2009), 'Così fan tutte', Financial Times, 20 June, http://www.ft.com/cms/s/0/c2ba3dec-4f0b-11de-8c1000144feabdc0.html\#axzz2EP0xruqY. Accessed 2 November 2012.

Hayward, S. (2005), French National Cinema, 2nd ed., London: Routledge.

Higbee, W. (2007), 'Beyond the (trans)national: Towards a cinema of transvergence in postcolonial and diasporic francophone cinema(s)', Studies in French Cinema, 7:2, pp. $79-92$.

Higbee, W. and Hwee-Lim, S. (2010), 'Concepts of transnational cinema: Towards a critical transnationalism in film studies', Transnational Cinemas, 1:1, pp. 7-21 
Higgins, C. (2009), 'No Così relationship: Visa row scuppers ENO's bid to secure Abbas Kiarostami', The Guardian, 6 May, http://www.guardian.co.uk/culture/2009/may/06/eno-abbas-kiarostami-visa-cosifan-tutte-coliseum. Accessed 30 November 2012.

Kiarostami, A. (2008), Shirin, Paris: MK2 Productions. (2010), Copie conforme, Paris: MK2 Productions. (2012), Like Someone In Love, Tokyo/Paris: Eurospace/MK2 Productions.

Jaggi, M. (2009), ‘A life in cinema: Abbas Kiarostami’, The Guardian, 13 June, http://www.guardian.co.uk/film/2009/jun/13/abbas-kiarostami-film. Accessed 3 June 2012.

James, I. (2007), 'The evidence of the image', L'Esprit Créateur, 47:3, Fall, pp. 68-79.

Libiot, E. (2008), 'Cosi fa Kiarostami', L’Express, 26 June, p. 108.

McMillan, J. (2008). 'Looking At Tazieh', The Scotsman, 18 August, http://www.scotsman.com/news/theatre-review-tazieh-1-1086113. Accessed 5 November 2012. 
Mondzain, M.-J. (2007), 'Looking At Tazieh: l'épopée et l'intimité', Cahiers du cinéma, 626, September, pp. 18-19.

Mulvey, L. (2002), 'Afterword', in R. Tapper (ed.), The New Iranian Cinema, London: I. B. Tauris, pp. 254-61. (2005), Death 24 XA Second, London: Reaktion.

Naficy, H. (2001), An Accented Cinema: Exilic and Diasporic Filmmaking, Princeton: Princeton University Press.

Nancy, J.-L. and Kiarostami, A. (2001), L'Évidence du film, Brussels: Y. Gevaert.

Rollet, S. (1997), 'Une esthétique de la trace', Positif, 422, December, pp. 90-93.

Sabouraud, F. (2010), Abbas Kiarostami: Le cinéma revisité, Rennes: Presses universitaires de Rennes.

Saljoughi, S. (2012), 'Seeing, Iranian style: Women and collective vision in Abbas Kiarostami's Shirin', Iranian Studies, 45:4, pp. 519-35. 
Tarr, C. (2011), 'Jewish-Arab relations in French, Franco-Maghrebi and Maghrebi cinemas', in W. Higbee and S Leahy (eds), Studies in French Cinema: UK Perspectives 1985-2010, Bristol: Intellect, pp. 321-36.

Viola, B. (2008), 'Moving image world', in Tristan und Isolde programme, Paris: Opéra national de Paris, pp. 34-35.

\section{Contributor details}

Jenny Chamarette is Lecturer in Film Studies at Queen Mary, University of London, and specializes in film philosophy and theorizations of contemporary film and art. She is the author of Phenomenology and the Future of Film: Rethinking Subjectivity beyond French Cinema (2012), and has published on installation art, photography and continental philosophy. Her current research focuses on theorizations of cinema and the museum, intermedial and transcultural exhibition practices.

\section{Contact:}

School of Languages, Linguistics and Film, Queen Mary, University of London, Mile End Road, London E1 4NS, UK.

E-mail: j.chamarette@qmul.ac.uk 